\title{
Reforming the World Health Organization
}

Devi Sridhar

University of Oxford

Lawrence O. Gostin

Georgetown University Law Center, gostin@law.georgetown.edu

Georgetown Public Law and Legal Theory Research Paper No. 11-34

This paper can be downloaded free of charge from:

https://scholarship.law.georgetown.edu/facpub/623

http://ssrn.com/abstract=1799432

JAMA, March 29, 2011, http://jama.ama-assn.org/content/early/2011/03/25/

jama.2011.418.full.pdf+html

This open-access article is brought to you by the Georgetown Law Library. Posted with permission of the author. Follow this and additional works at: https://scholarship.law.georgetown.edu/facpub

Part of the Health Law and Policy Commons 


\section{Reforming the World Health Organization}

Devi Sridhar, DPhil

Lawrence O. Gostin, JD

N DECEMBER 2010, JACK CHOW, ${ }^{1}$ THE FORMER WORLD Health Organization (WHO) assistant directorgeneral, asked, "Is the WHO becoming irrelevant?" A month later, the WHO's executive board considered the agency's future within global health governance. After a yearlong consultation with member states on its financing, Director-General Margaret Chan called the WHO overextended and unable to respond with speed and agility to today's global health challenges. ${ }^{2}$

The crisis in leadership is not surprising to those familiar with the WHO. As its first specialized agency, the United Nations (UN) endowed the WHO with extensive normative powers to act as the directing and coordinating authority on international health. Yet modern global health initiatives (eg, the Global Fund to Fight AIDS, Tuberculosis and Malaria and the GAVI Alliance [formerly the Global Alliance for Vaccines and Immunisation]), bilateral programs (eg, US President's Emergency Plan for AIDS Relief [PEPFAR]), and well-funded philanthropies (eg, the Bill \& Melinda Gates Foundation) often overshadow the agency. The WHO can be subject to political pressure, and its relationship with industry and civil society is uncertain. ${ }^{3}$

Given the importance of global health cooperation, few would dispute that a stronger, more effective WHO would benefit all. The WHO's internal reform agenda must be bold to ensure its future. In this Commentary, we offer 5 proposals for reestablishing the agency's leadership.

\section{Give Real Voice to Multiple Stakeholders}

As a UN agency, the WHO consists solely of member states, which govern through the World Health Assembly (WHA) and the executive board. Yet nonstate actors have become major stakeholders in global health, often shifting their resources to new initiatives with governance structures reflecting their power. Known in international relations as forum shopping, stakeholders choose specific institutions to pursue their interests. In contrast to the WHO, representatives from civil society, the private sector, and foundations sit on the boards of the Global Fund and the GAVI Alliance. Even UN agencies such as the Joint United Nations Programme on HIV/AIDS engage civil society through advisory committees.
The WHO would be more effective by giving voice and representation to key stakeholders, including philanthropies, businesses, public/private partnerships, and civil society. While actively engaging with the private sector, the WHO should also set standards for and ensure compliance of key private partners such as the food, pharmaceutical, and biotechnology industries. At the same time, conflict-of-interest rules for expert committees and contractors require clarity and enforcement.

The director-general is taking a major step in proposing a global health forum, which would include regular multistakeholder meetings under the guidance of the WHA. ${ }^{2}$ The global health forum must afford stakeholders real voice and representation, effectively shaping the WHO's decisions. The WHA should also pass a resolution lowering the bar to official nongovernmental organization status. Meaningful stakeholder engagement would instill confidence and spark investment in the agency.

\section{Improve Transparency, Performance, and Accountability}

Good governance also requires clear objectives, transparent decision making, information dissemination, monitoring progress, and accountability. Stakeholders demand clarity on how their resources will achieve improved health outcomes as they shift toward results-based financing and performance-based measures. Yet a recent evaluation of multilateral organizations graded the WHO as weak on key parameters such as cost-consciousness, financial management, public disclosure, and fulfilling development objectives. ${ }^{4}$ To improve its standing, the WHO must make it easier for stakeholders to monitor achievements and demonstrate that activities effectively translate into better health outcomes.

\section{Closer Oversight of Regions}

The WHO's decentralized, regional structure poses a significant challenge in demonstrating results and delivering on priorities. The $6 \mathrm{WHO}$ regional offices are uniquely independent within the UN system, with full power over regional personnel, including appointment of country representatives. Regional committees meet annually to formulate

Author Affiliations: Department of Politics and International Relations, University of Oxford, Oxford, England (Dr Sridhar); and O'Neill Institute for National and Global Health Law, Georgetown University Law Center, Washington, DC (Mr Gostin). Corresponding Author: Lawrence O. Gostin, JD, Georgetown University Law Center, 600 New Jersey Ave NW, Washington, DC 20001 (gostin@law.georgetown.edu). 
policies, review the regional program budget, and monitor the WHO's collaborative activities for health. The WHA and the executive board formally approve decisions, but in practice do not provide tight policy and budgetary control.

The headquarters of the WHO should exercise more oversight and control over regional personnel and decision making. Minimally, the agency should fully disclose the funds held within each regional office and how regions meet health objectives, with monitoring and benchmarks of success. Even if decentralized decision making remains the norm, the WHO should apply the same yardstick across regions to assess efficiency and effectiveness.

\section{Exert Legal Authority as a Rule-Making Body}

The WHO's constitution grants the agency extraordinary rulemaking powers, but the agency has promulgated only $2 \mathrm{ma}$ jor treaties in more than 60 years: the International Health Regulations and the Framework Convention on Tobacco Control. The WHO could take a more active role in regulating for the world's health on key issues, including counterfeit medicines, alcoholic beverages, food safety, and nutrition. It could be far more engaged and influential in international regimes with powerful health impacts such as trade, intellectual property, arms control, and climate change.

The agency could exert normative power through innovative treaties (eg, a Framework Convention on Global Health) or through soft power (eg, codes of practice) with strong incentives for compliance. ${ }^{5}$ The WHO must offer leadership for urgent challenges facing the global health system such as the need to set clear priorities, facilitate coherence among currently fragmented actors, and ensure fair burden sharing among states.

\section{Ensure Predictable, Sustainable Financing}

The WHO is financed through 2 main streams. First, member states pledge a specified proportion of total assessed contributions calculated according to each country's wealth and population. The WHA then unanimously approves a core budget. The second stream is through voluntary contributions often earmarked for specific diseases, sectors, or countries. The development assistance committee of the Organisation for Economic Co-operation and Development calls extrabudgetary funding "multi-bi" aid (ie, donors routing noncore funding allocated for specific purposes through multilateral agencies) ${ }^{6}$

The WHO's biennial budget more than doubled from US $\$ 1.6$ billion in 1998-1999 to US $\$ 4.2$ billion in 2008-2009, but the agency has a dire budget deficit of US $\$ 300$ million this year. More importantly, its extrabudgetary budget increased from $48.8 \%$ to $77.3 \%$ during that period. ${ }^{7}$ It is not sustainable to have voluntary funding represent nearly $80 \%$ of the agency's budget.

Moreover, extrabudgetary funding skews global health priorities. Assessed contributions are more aligned with the actual global burden of disease than extrabudgetary funding. For example, in 2008-2009, the WHO's extrabudgetary funding was primarily for infectious diseases $(60 \%)$ and had neg- ligible allocations for noncommunicable diseases (3.9\%) and injuries (3.4\%). ${ }^{7}$ Yet noncommunicable diseases account for $62 \%$ of all deaths worldwide, ${ }^{8}$ and injuries account for $17 \%$ of the global burden of disease. ${ }^{9}$

The director-general's report proposes broadening the base for flexible, unearmarked funding by attracting new donors such as foundations, emerging economies, and the private sector. ${ }^{2}$ Although worthwhile, these stakeholders are unlikely to behave differently than traditional donors, and probably will prefer to control their funds through earmarks. The ideal solution would be for the WHA to set higher member state contributions. Member states must become genuine shareholders in WHO's future, act collectively, and refrain from exerting narrow political interests. Failing decisive WHA action, the WHO could consider charging overheads of $20 \%$ to $30 \%$ for voluntary contributions to supplement its core budget. Although overheads are a familiar model in academia, the WHO would have to guard against the risk that charges might drive donors toward other multilateral organizations.

\section{Global Health Leadership}

If the WHO is to hold its rightful place as the leader in global health governance, the organization must undergo fundamental reform. There is no substitute for the WHO, with its progressive constitution and global legitimacy. It is not likely that the same powers would be granted to an international organization if it were created today. Consequently, while remaining true to its normative and bold vision of health for all, the WHO must adapt to a new political climate, demonstrate global leadership, and deliver results.

Published Online: March 29, 2011. doi:10.1001/jama.2011.418 Conflict of Interest Disclosures: All authors have completed and submitted the ICMJE Form for Disclosure of Potential Conflicts of Interest. Mr Gostin is director of the World Health Organization's Collaborating Center on Public Health Law and Human Rights. He also serves on the director-general's Ad hoc Advisory Committee on the World Health Organization and Global Health Governance.

Additional Contributions: We thank Eric A. Friedman, JD, and Emily A. Mok, DPhil, both O'Neill Institute Fellows, for valuable research and editing; neither of whom was compensated financially for these contributions.

\section{REFERENCES}

1. Chow JC. Is the WHO becoming irrelevant? http://www.foreignpolicy.com /articles/2010/12/08/is_the_who_becoming_irrelevant. Accessibility verified March 18, 2011.

2. World Health Organization. Future of financing for WHO. http://apps.who .int/gb/ebwha/pdf_files/EB128/B128_21-en.pdf. Accessibility verified March 18, 2011.

3. Godlee F. WHO in crisis. BMJ. 1994:309(6966):1424-1428.

4. Department for International Development. Multilateral aid review. https: //s3-eu-west-1.amazonaws.com/media.dfid.gov.uk/multilateral_aid_review full_linked.pdf. Accessibility verified March 18, 2011.

5. Gostin LO, Heywood M, Ooms G, et al. National and global responsibilities for health. Bull World Health Organ. 2010;88(10):719-719A.

6. Organisation for Economic Co-operation and Development; Development Assistance Committee. 2010 DAC [development assistance committee] report on multilateral aid. http://www.oecd.org/dataoecd/23/17/45828572.pdf. Accessibility verified March 18, 2011.

7. Sridhar D, Woods N. Trojan multilateralism: the changing face of global cooperation. Paper presented at: International Studies Association 52nd Annual Convention; March 16, 2011; Montreal, Quebec, Canada.

8. World Health Organization. World Health Statistics 2010. Geneva, Switzerland: World Health Organization; 2010:70.

9. World Health Organization. Global Burden of Disease. Geneva, Switzerland: World Health Organization; 2010:48,58. 